\title{
Rheological behavior study and its significance in the assessment of application properties and physical stability of phytosome loaded hydrogels
}

\section{Ljiljana Djekic $^{1}$, Danina Krajišnik ${ }^{*}$}

${ }^{1}$ University of Belgrade - Faculty of Pharmacy, Department of Pharmaceutical Technology and Cosmetology, Vojvode Stepe 450, 11221 Belgrade, Serbia

*Corresponding author: Danina Krajišnik, E-mail: danina.krajisnik@pharmacy.bg.ac.rs

\begin{abstract}
Phytosomes are amphiphilic molecular complexes of substances of plant origin and phospholipids that are considered as active ingredients of dermopharmaceutical and cosmetic formulations of potentially improved efficiency. The study aim was the formulation of carbomer hydrogels with commercially available phytosomes of escin (Escin B-Sitosterol Phytosome ${ }^{\circledR}$ ) (EP) and 18-ß glycyrrhetinic acid (18-ß Glycyrrhetinic Acid Phytosome ${ }^{\circledR}$ ) (GP) and evaluation of their application properties and real-time physical stability. Phytosomes incorporation did not significantly affect $\mathrm{pH}$ of the hydrogels, which was acceptable for cutaneous application. However, these hydrogels had significantly different organoleptic properties (opaque and softer consistency) compared to the hydrogel without active substance (C) and the hydrogels with pure active substances ( $E$ and $G$ ) used for comparison. The values of maximum and minimum apparent viscosity and yield stress were significantly lower in phytosome-loaded hydrogels. The results of oscillatory rheological analysis indicated that viscous character prevails in EP and GP hydrogels (elastic modulus $\left(G^{\prime}\right)<$ viscous modulus $\left(G^{\prime \prime}\right)$ ), while in hydrogels $C, E$ and $G$ elastic properties were more pronounced $\left(G^{\prime}>G^{\prime \prime}\right)$. Escin phytosome had greater influence on carbomer gel network strength. Phytosome-loaded hydrogels were physically stable during 24 months of storage under ambient conditions, although the rheological analysis also indicated a potential risk of sedimentation.
\end{abstract}

Keywords: phytosomes, hydrogel, rheological characterization, application properties, physical stability

doi.org/10.5937/arhfarm71-30708 


\section{Introduction}

Phytosome is a novel form of active substances of plant origin obtained by building a molecular complex between standardized plant extracts or isolated active substances and phospholipids in a stoichiometric ratio (1). The subjects of complexation are phytoconstituents that have poor solubility in water and/or oils that compromises the development of stable formulations, as well as limits their permeability through biological barriers, and the achievement of the desired pharmacological or cosmetic efficacy (2). The formation of these specific complexes yields new chemical entities which have physicochemical properties different from the pure phytoconstituents, including increased solubility and balanced oil-to-water partition coefficient (3). Several articles have already reviewed the enhanced aqueous solubility and in vitro and/or in vivo percutaneous permeability of different phytosomes (2-4). Although the phytosomes that are commercially available as standard quality raw materials for dermopharmaceutical or cosmetic use are becoming an important technological strategy $(5,6)$, the number of phytosome-loaded formulations for cutaneous administration is still very limited. Phytoconstituent-phospholipid complexes are considered amphiphilic molecules and they are thus especially suitable for incorporation in aqueous vehicles where intermolecular interactions and self-association can occur $(3,4)$. Hydrogels, as soft semisolids comprising a large amount of aqueous phase which is embedded in the three-dimensional polymer network, may be particularly suitable vehicles due to their ease of application, good spreading ability, retention at the administration site, and cooling effect which is the consequence of the rapid evaporation of the liquid phase (7-11). Moreover, it was found that the release of molecules of active substances from the vehicle takes place over a relatively longer period of time upon their inclusion into larger structures (e.g. vesicles, microparticles, micelles) that are suspended in the semisolid hydrogel matrix $(12,13)$. Hydrogels are non-Newtonian systems with yield stress (a threshold value of stress, below which they behave as elastic solids, and above which they flow as viscous fluids) and shear thinning/thickening properties (i.e. their viscosity is a function of an increasing/decreasing shear rate, respectively) $(14,15)$. The application properties of hydrogels largely depend on formulation factors that may affect the rheological characteristics of the system, including physico-chemical properties and concentrations of a gelling agent and an active substance. The most often used gelling agents in topical hydrogels are carbomers, which represent high-molecular homo-polymers of acrylic acid crosslinked by polyethers $(16,17)$. Carbomer hydrogels are viscoelastic systems obtained by the dispersion of polymer powders in water and subsequent neutralization with a suitable base, so that the dry particles swell, and polymer chains undergo extensive expansion (15). Several studies have shown that interactions between carbomer chains and amphiphilic substances, such as anionic, cationic and nonionic surfactants, may cause changes in the rheological properties of their aqueous dispersions and hydrogels (18-20). The influence of amphiphilic phytosomes on the structure and strength of carbomer-based 
hydrogels and corresponding rheological and application characteristics, have not been evaluated so far.

Escin $ß$-Sitosterol Phytosome ${ }^{\circledR}$ (Indena, Italy) is an amorphous powder dispersible in water and soluble in propylene glycol, obtained by the formation of the complex of hydrophilic crystalline escin $(32-40 \%)$ with the lipophilic $\beta$-sitosterol and the amphiphilic phosphatidylcholine (21). Topical Escin B-Sitosterol Phytosome ${ }^{\circledR}$ is recommended as a microcirculation and orange peel skin condition improver, suitable for body, legs, and foot care products, anti-cellulite products, to reduce eye puffiness (21). Hydrogels with 3\% Escin $\beta$-Sitosterol Phytosome ${ }^{\circledR}$ did not cause sensitization and skin irritation of human volunteers $(22,23)$ and a recent study $(24)$ showed that carbomer hydrogels with $1-5 \%$ of Escin $B$-Sitosterol Phytosome ${ }^{\circledR}$ did not cause skin irritation in rats. 18- $\beta$ Glycyrrhetinic Acid Phytosome ${ }^{\circledR}$ (Indena, Italy) represents an amorphous water dispersible complex of 18- $\beta$ glycyrrhetinic acid $(27-31 \%)$ and phosphatidylcholine, recommended for topical formulations with anti-inflammatory, anti-irritant, antierythema and soothing effects in medical devices, after sun, after waxing, aftershave products, skin care products for dry and sensitive skin, and for an anti-puffiness effect in the eye area $(25,26)$. In our previous studies, carbomer hydrogels with phytosomes of escin (24) and 18- $\beta$ glycyrrhetinic acid (27) were formulated. The characterization of these hydrogels during short-term (3 months) accelerated (27) and in-use (24) physical stability studies, indicated changes in rheological parameters, such as apparent viscosity and thixotropy. However, during these studies, the type of packaging container (closed tube), storage conditions (room temperature), and real-time study duration (few years), under which the obtained results could be used to assess the inherent physical stability and application properties of the phytosome loaded hydrogels, were not considered. Moreover, oscillatory rheological characterization which could be used for the evaluation of the phytosome influence on the degree of ordering of the polymer network of the carbomer hydrogel was not performed.

The aim of the study was to formulate and characterize carbomer hydrogels with Escin $\beta$-Sitosterol Phytosome ${ }^{\circledR}$ and 18- $\beta$ Glycyrrhetinic Acid Phytosome ${ }^{\circledR}$ in order to assess the influence of phytosome incorporation on the polymer network strength, as well as the application properties and physical stability of hydrogels during the two-year physical stability study. A particular focus of the study was to consider the importance of comprehensive rheological analysis in the evaluation of application and physical stability aspects of the phytosome-loaded hydrogel formulations. 


\section{Materials and methods}

\section{Materials}

The components of the hydrogel base were: carbomer (Carbopol ${ }^{\circledR}$ Ultrez 10 polymer, Lubrizol, USA), triethanolamine (Sigma Aldrich/Merck, Germany), isopropyl alcohol (Fagron, The Netherlands), propylene glycol (Fagron, The Netherlands), and purified water (Ph. Eur. 10.0). Escin ß-Sitosterol Phytosome ${ }^{\circledR}$ (Lecithin (syn. Phosphatidylcholine) (CAS 8002 - 43 - 5) (and) Escin (CAS 6805 - 41 - 0) (and) $\beta$-Sitosterol (CAS 83 - 46 - 5)), escin (CAS 6805 - 41 - 0), 18- $\beta$ Glycyrrhetinic Acid Phytosome $^{\circledR}$ (Lecithin (syn. Phosphatidylchiline) (CAS 8002-43-5) (and) Glycyrrhetinic Acid (471- 53 - 4)), and 18-ß glycyrrhetinic acid (CAS 471 - 53 - 4) were obtained from Indena (Italy) as free samples.

\section{Methods}

\section{Preparation of hydrogels}

The hydrogel base $(\mathrm{C})$ was prepared with $1 \%$ of carbomer, which is the common concentration of this type of gelling agents in semisolid hydrogels $(7,8)$. The liquid phase of the hydrogel consisted of isopropyl alcohol (25\%) (a cosolvent), propylene glycol $(10 \%)$ (a humectant), and water (63\%). To prepare the hydrogel base, carbomer powder was dispersed directly in water using laboratory propeller mixer IKA RW 20 digital (IKA ${ }^{\circledR}$-Werke $\mathrm{GmbH} \&$ Co. KG, Staufen, Germany) at a moderate speed of $300 \mathrm{rpm}$, at room temperature. The obtained polymer dispersion was neutralized by adding the neutralizing agent triethanolamine (1\%), and after that, propylene glycol $(10 \%)$ and isopropyl alcohol (25\%) were admixed under continuous stirring. The hydrogel base was stored in a refrigerator for $24 \mathrm{~h}$ and used to prepare the hydrogels with active substances immediately afterwards.

The active substances incorporated in the hydrogel base were escin and 18- $\beta$ glycyrrhetinic acid in the form of phytosomes (Escin $\beta$-Sitosterol Phytosome ${ }^{\circledR}$ and 18- $\beta$ Glycyrrhetinic Acid Phytosome ${ }^{\circledR}$, respectively). Also, for comparison, two corresponding hydrogels with pure escin 1\% (E) and pure 18-ß glycyrrhetinic acid 1\% (G) were prepared. In order to eliminate the significance of the pure active substance content, the concentration of Escin $\beta$-Sitosterol Phytosome ${ }^{\circledR}$ in the prepared hydrogel (EP) was $2.78 \%$ which is equivalent to $1 \%$ of escin, while, in the hydrogel with $18-\beta$ Glycyrrhetinic Acid Phytosome ${ }^{\circledR}$ (GP), the concentration of the active substance in the form of phytosomes was $3.38 \%$, which corresponded with $1 \%$ of $18-\beta$ glycyrrhetinic acid, in accordance with the manufacturer's specifications $(21,25)$.

The composition of the hydrogel base and the hydrogels with the active substances is shown in Table I. 
Table I Composition of the hydrogel base (C) and the hydrogels with Escin $\beta$-Sitosterol Phytosome $^{\circledR}$ (EP), 18-ß Glycyrrhetinic Acid Phytosome ${ }^{\circledR}$ (GP), escin (E) and 18- $\beta$ glycyrrhetinic acid $(\mathrm{G})$ (concentration of the ingredients is expressed in weight percentages)

Tabela I Sastav hidrogel podloge (C) i hidrogelova sa fitosomima escina (Escin B-Sitosterol Phytosome $^{\circledR}$ ) (EP), fitosomima 18-ß gliciretinske kiseline (18- $\beta$ Glycyrrhetinic Acid Phytosome ${ }^{\circledR}$ ), escinom (E) i 18-ß gliciretinskom kiselinom (G) (koncentracije sastojaka izražene su u masenim procentima)

\begin{tabular}{|l|c|c|c|c|c|}
\hline \multirow{2}{*}{ Composition } & \multicolumn{5}{|c|}{ Sample } \\
\cline { 2 - 6 } & C & EP & GP & E & G \\
\hline Carbomer (\%) & 1 & 0.97 & 0.97 & 0.99 & 0.99 \\
\hline Trietanolamin (\%) & 1 & 0.97 & 0.97 & 0.99 & 0.99 \\
\hline Water (\%) & 63 & 61.25 & 60.86 & 62.37 & 62.37 \\
\hline Propylene glycol (\%) & 10 & 9.72 & 9.66 & 9.9 & 9.9 \\
\hline Isopropyl alcohol (\%) & 25 & 24.31 & 24.16 & 24.75 & 24.75 \\
\hline Escin ß-Sitosterol Phytosome ${ }^{\circledR}(\%)$ & - & 2.78 & - & - & - \\
\hline $\begin{array}{l}18-\beta \text { Glycyrrhetinic Acid } \\
\text { Phytosome }{ }^{\circledR}(\%)\end{array}$ & - & - & 3.38 & - & - \\
\hline Escin (\%) $^{*}$ (\%) & - & - & - & 1 & - \\
\hline $18-\beta$ glycyrrhetinic acid (\%) & - & - & - & - & 1 \\
\hline
\end{tabular}

Each of the four hydrogels loaded with a different active substance was prepared by mixing a precisely measured amount of the corresponding active substance with the required amount (up to $100 \%$ relative to the concentration of the active substance) of a previously prepared hydrogel base. The preparation procedure for all hydrogels with active substances was the same, in order to exclude the importance of the preparation process conditions for the examined rheological and application properties of hydrogels and their physical stability. Half of the total amount of hydrogel base $\mathrm{C}$ was weighed into the laboratory beaker, and then the active substance was added while stirring for 15 minutes by a laboratory propeller mixer IKA RW 20 digital (IKA ${ }^{\circledR}$-Werke GmbH \& Co. $\mathrm{KG}$, Staufen, Germany) at a speed of $300 \mathrm{rpm}$, at room temperature. The remaining amount of the hydrogel base was then added and stirring was continued at the same speed for another 15 minutes. Each hydrogel (C, E, EP, G, GP) was packed in an appropriate number of tubes, so that the samples from one tube were used for each test point set over 24 months. 


\section{Characterization of hydrogels}

In order to perceive application properties, such as the ease of smearing and the ability to spread and retain the film formed on the skin, the values of continual rheological parameters (minimal and maximal apparent viscosity, yield stress and hysteresis area) of the hydrogels were measured at defined time intervals during two years of natural aging (7 days, 1 month, 3 months, 6 months, and 24 months). In addition, the acceptability for application to the skin was checked by measuring the $\mathrm{pH}$ value of the hydrogel samples for the duration of the study.

For the assessment of physical stability, the hydrogels were packed in well-closed aluminium tubes and stored under ambient conditions at $20 \pm 5{ }^{\circ} \mathrm{C}$ for 24 months. The aging of the hydrogels was checked periodically, after 7 days, 1 month, 3 months, 6 months, and 24 months, by organoleptic examination and oscillatory rheological analysis, which enabled the evaluation of their viscoelastic properties.

\section{Examination of organoleptic properties}

A sample of each hydrogel in the amount of approximately $1 \mathrm{ml}$ was extruded from the tube upon the first opening on a glass microscope plate. The extruded samples were left to stand for $15 \mathrm{~min}$ at room temperature and exposed to air, and then their odor and appearance (color, homogeneity, transparency or turbidity, and tendency to spill spontaneously on the flat plate) were observed, and they were photographed in sunlight using a Canon IXUS 180 camera (Canon, Japan).

\section{Measurement of pH}

The $\mathrm{pH}$ of the hydrogel samples was measured by a direct potentiometric method with a HI $8417 \mathrm{pH}$ meter (Hanna Instruments, USA), at a temperature of $20 \pm 3{ }^{\circ} \mathrm{C}$. The $\mathrm{pH}$ meter was pre-calibrated using the standard buffer solutions of $\mathrm{pH} 4.0$ and 7.0.

\section{Rheological measurements}

Rheological measurements were performed using a Rheolab MC 120 rotational rheometer (Paar Physica, Stuttgart, Germany) coupled with an MK 22 cone and plate measuring device (diameter $50 \mathrm{~mm}$, angle $1^{\circ}$, gap $50 \mu \mathrm{m}$ ) at room temperature $\left(20 \pm 0.2^{\circ} \mathrm{C}\right)$. For continuous (rotational) flow tests, the CSR (controlled shear rate) procedure was selected for a flow curve evaluation by the linear increasing of the shear rate from 0 to $200 \mathrm{1} / \mathrm{s}$ and decreasing it back to $01 / \mathrm{s}$, each stage lasting $100 \mathrm{~s}$. For yield stress $\left(\tau_{0}\right)$ determination, flow curve measurements in the same shear rate ranges by logarithmic increase and decrease were completed (28).

Oscillatory (dynamic) measurements were performed to determine the linear viscoelastic region of the hydrogels. For the determination of the linear viscoelastic region, the applied deformation was increased in the range $0.6-100 \%$ under a constant frequency of $1 \mathrm{~Hz}$. Afterwards, a frequency sweep ramp from 0.1 to $10 \mathrm{~Hz}$ was performed at the constant strain of 5\%, within the previously determined linear viscoelastic region 
for all the samples. The values of elastic $\left(\mathrm{G}^{\prime}\right)$ and viscous $\left(\mathrm{G}^{\prime \prime}\right)$ moduli, and the damping factor $(\tan \delta)$ were used for the characterization of the hydrogels. All rheological measurements were done in triplicate.

\section{Results and discussion}

\section{Organoleptic properties of the hydrogels}

All the investigated freshly prepared hydrogels were homogeneous soft semisolids with isopropyl alcohol odor. The carbomer hydrogel base without active substance (C) was homogeneous, colorless, and transparent soft semisolid. No spontaneous spillage of the hydrogel $\mathrm{C}$ sample on the glass plate was observed (Figure 1).
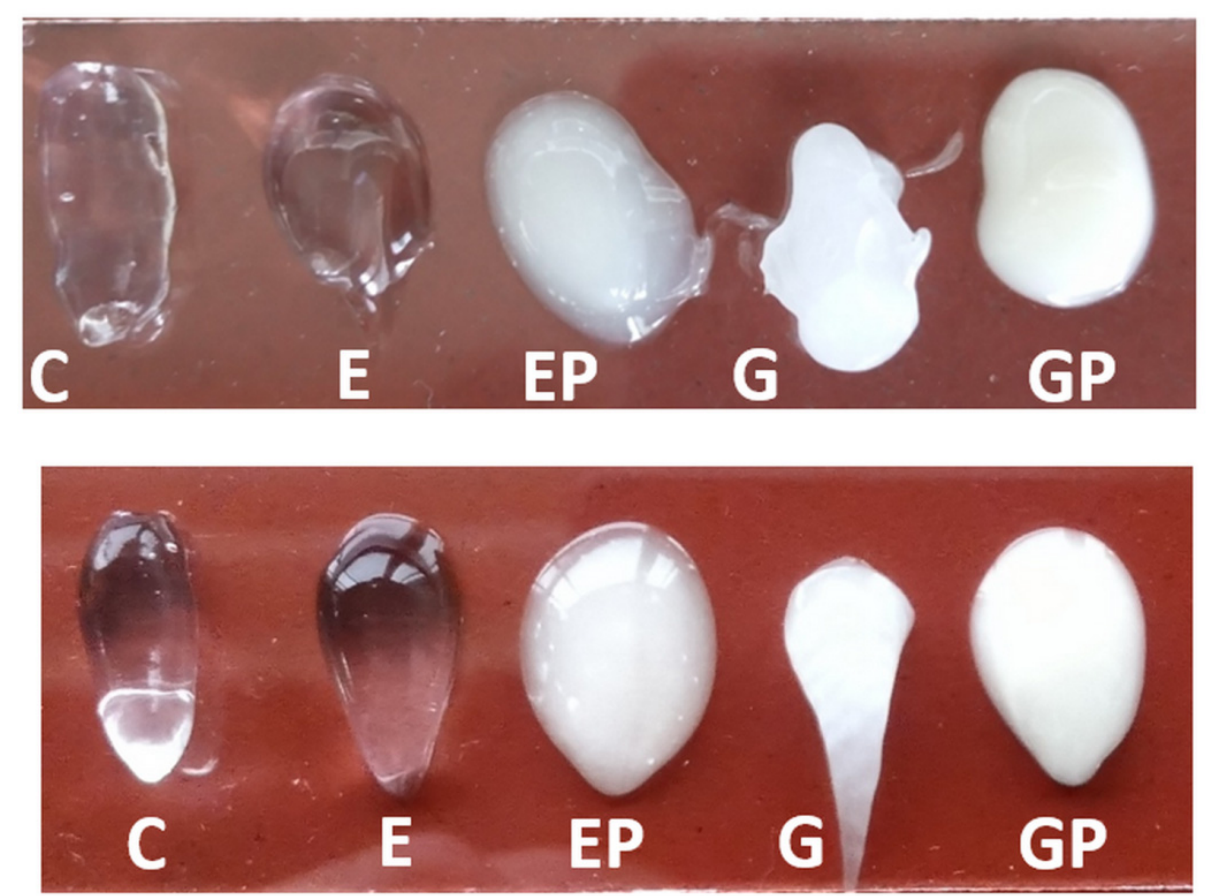

Figure 1. Appearance of the hydrogel without active substance $(C)$ and the hydrogels comprising: escin (E), Escin ß-Sitosterol Phytosome ${ }^{\circledR}$ (EP), 18-ß glycyrrhetinic acid (G), and 18-ß Glycyrrhetinic Acid Phytosome ${ }^{\circledR}$ (GP) (after 7 days (above) and after 24 months (below))

Slika 1. Izgled hidrogela bez aktivne supstance (C) i hidrogelova koji sadrže: escin (E), Escin ß-Sitosterol Phytosome ${ }^{\circledR}$ (EP), 18-ß gliciretinsku kiselinu (G) i 18-ß Glycyrrhetinic Acid Phytosome ${ }^{\circledR}$ (GP) (nakon 7 dana (gore) i nakon 24 meseca (dole))

Although the investigated hydrogels with active substances were prepared with the same hydrogel base, their appearance and consistency differed. The hydrogel with escin (E) was also colorless and transparent (Figure 1). Escin is soluble in the aqueous phase 
of the hydrogel (29), so it did not significantly affect its optical characteristics. Hydrogel E did not spill spontaneously on the surface of the glass plate. However, the hydrogel with escin in the form of phytosomes (EP) was homogeneous and turbid, due to the limited solubility of the active substance in water (29), with a consistency visibly softer compared to hydrogels $\mathrm{C}$ and $\mathrm{E}$. It was observed that, after squeezing out of the tube, after 7 days of storage, it spilled spontaneously on the glass plate (Figure 1). G and GP gels were milky white (Figure 1 ) due to the limited solubility of both pure $18-\beta$ glycyrrhetinic acid and the phytosome form, in the aqueous phase of the carbomer hydrogel (30). The consistency of $\mathrm{G}$ was similar to $\mathrm{C}$, but GP was slightly softer than both $\mathrm{G}$ and $\mathrm{C}$. After the application of hydrogel $\mathrm{G}$ stored for 7 days at room temperature on the glass plate, there was no spillage, while hydrogel GP was softer, and a spontaneous spillage was observed (Figure 1).

\section{Application properties of the hydrogels}

All the investigated hydrogels were suitable for easy smearing on the skin. Each hydrogel spread out easily on the skin and evaporated quickly, leaving a thin, non-sticky vanishing film, and a sense of cooling that can be potentiated by the rapid evaporation of isopropyl alcohol.

The $\mathrm{pH}$ values of the hydrogels with active substances (E, EP, G, and GP) and the hydrogel base (C) are shown in Table II.

Table II The $\mathrm{pH}$ values of the hydrogel base (C) and the hydrogels with escin (E), Escin ß-Sitosterol Phytosome ${ }^{\circledR}$ (EP), 18-ß glycyrrhetinic acid (G) and 18-ß Glycyrrhetinic Acid Phytosome ${ }^{\circledR}$ (GP) during storage period

Tabela II pH vrednosti hidrogel podloge (C), hidrogelova sa escinom (E), fitosomima escina (Escin $\beta$-Sitosterol Phytosome ${ }^{\circledR}$ ) (EP), 18-ß gliciretinskom kiselinom (G) i fitosomima 18-ß gliciretinske kiseline (18-ß Glycyrrhetinic Acid Phytosome ${ }^{\circledR}$ ) tokom period čuvanja

\begin{tabular}{|c|c|c|c|c|c|}
\hline \multirow{2}{*}{ Sample label } & \multicolumn{5}{|c|}{ Storage period } \\
\cline { 2 - 6 } & 7 days & 1 month & 3 months & 6 months & 24 months \\
\hline C & 6.29 & 6.29 & 6.31 & 6.30 & 6.30 \\
\hline E & 6.43 & 6.41 & 6.44 & 6.42 & 6.46 \\
\hline EP & 6.21 & 6.20 & 6.16 & 6.19 & 6.24 \\
\hline G & 6.65 & 6.67 & 6.67 & 6.68 & 6.70 \\
\hline GP & 6.34 & 6.30 & 6.27 & 6.27 & 6.25 \\
\hline
\end{tabular}


The $\mathrm{pH}$ values of the hydrogels with escin and $18-\beta$ glycyrrhetinic acid, pure as well as their phytosomal forms, were between 6.16 and 6.70 , thus considered acceptable for the application to the skin without risk of irritation (31).

In our previous study (24), it was observed that the escin loaded carbomer (Carbopol ${ }^{\circledR}$ 934) hydrogels had lower $\mathrm{pH}$ and softer consistency compared to the hydrogel base itself, and this effect of escin was concentration-dependent. However, such correlation was not observed in the hydrogels with escin in the form of phytosomes. To allow for a comparison of results, in the present study, the $\mathrm{pH}$ value of the hydrogel base (C) was set to be as close as possible to the $\mathrm{pH} 6.25$ of the $1 \%$ escin hydrogel formulated in the previous study (24). The $\mathrm{pH}$ of the freshly prepared hydrogel base $\mathrm{C}$ was 6.30 . The average $\mathrm{pH}$ value of the hydrogel base $\mathrm{C}$ was $6.30 \pm 0.01$ and could be considered unchanged throughout the 24-month test period. The hydrogels with escin had an average $\mathrm{pH}$ of $6.43 \pm 0.02$ during the 24 -month monitoring. The EP hydrogel had an average $\mathrm{pH}$ of $6.20 \pm 0.03$, and it can be considered that the $\mathrm{pH}$ value did not change significantly during the study. In both cases, the $\mathrm{pH}$ values of hydrogels $\mathrm{E}$ and $\mathrm{EP}$ were very similar, with the value of this parameter measured for hydrogel base $\mathrm{C}$. However, the consistency of EP hydrogel, containing an equivalent concentration of escin in the form of phytosome, was much softer in comparison to $\mathrm{C}$ and $\mathrm{E}$, despite the similar $\mathrm{pH}$ values. Based on this observation, it was assumed that phytosome form of the escin could affect the structure of the carbomer hydrogel, and rheological measurements were necessary for a more precise characterization.

The average $\mathrm{pH}$ values of the hydrogels $\mathrm{G}$ and GP were $6.67 \pm 0.02$ and $6.29 \pm 0.04$, respectively. In both cases, variations in $\mathrm{pH}$ values throughout the 24 -mont study period were negligible. The dispersion of $18-\beta$ glycyrrhetinic acid in the carbomer hydrogel base increases its average $\mathrm{pH}$ by approximately $0.37 \mathrm{pH}$ units. It can be assumed that the suspension of $18-\beta$ glycyrrhetinic acid disrupts the three-dimensional network structure of the closely packed swollen microgels (32), making carbomer polymer chains more accessible for neutralization, so that the number of neutralized carboxyl groups is slightly increased, which is manifested by an increase in the $\mathrm{pH}$ of the bulk hydrogel. In contrast, there was almost no difference between the average $\mathrm{pH}$ of hydrogel GP and the average $\mathrm{pH}$ of hydrogel base $\mathrm{C}$. This observation was in line with the previously noted high compatibility of Carbopol ${ }^{\circledR}$ Ultrez 10 based hydrogels with 18- $\beta$ Glycyrrhetinic Acid Phytosome $^{\circledR}$, and a negligible effect of this active substance on $\mathrm{pH}$ of the carbomer hydrogel itself (27). As in the case of escin, the effect of 18-\$ glycyrrhetinic acid in the form of phytosomes on $\mathrm{pH}$ was negligible, but this phytosome also significantly affected the consistency of the carbomer hydrogel. In order to assess this impact, a detailed rheological characterization was necessary.

The rheological characterization of carbomer base $\mathrm{C}$, as well as the hydrogels with the active substances, revealed non-Newtonian, shear-thinning plastic flow behavior (Figure 2). 
a)

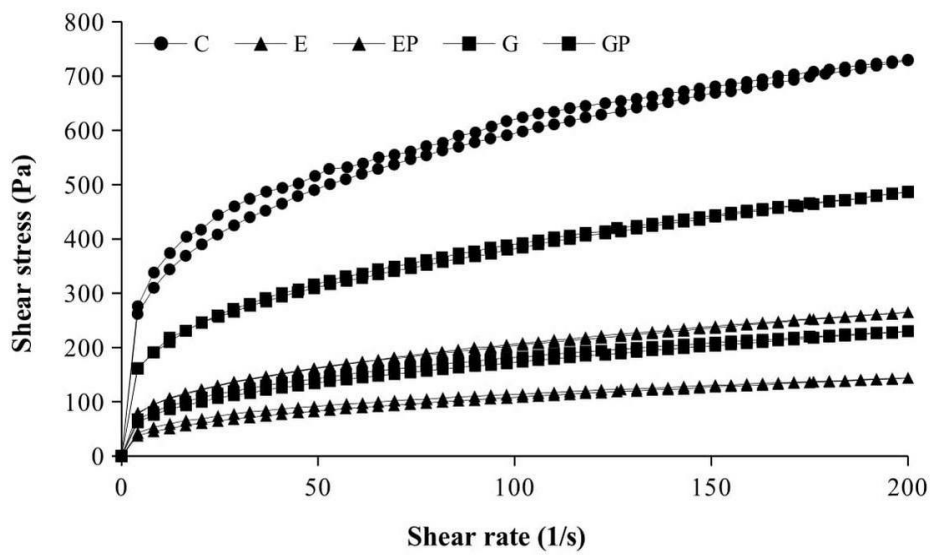

b)

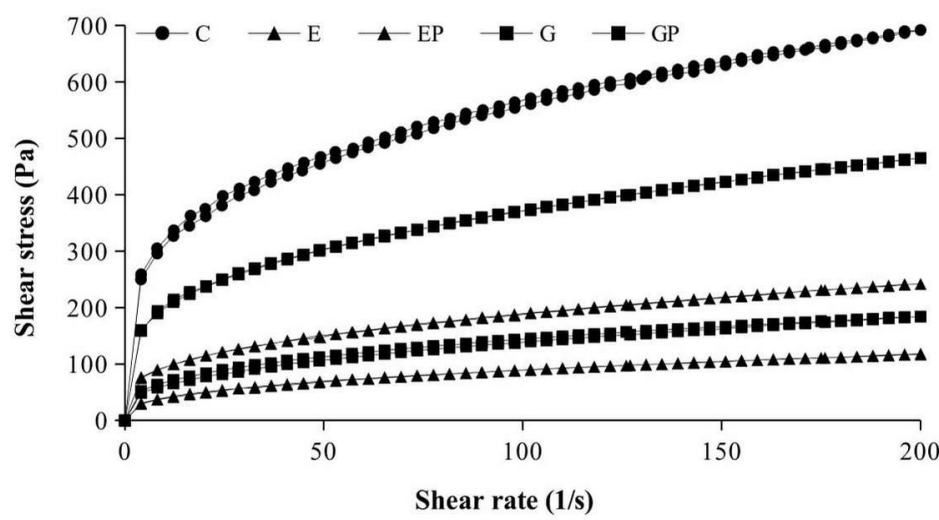

c)

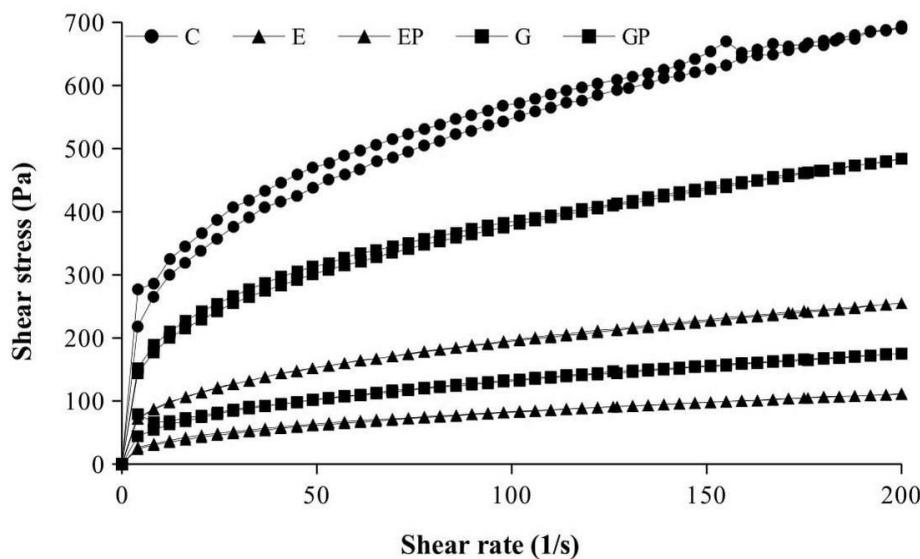

Figure 2. Flow curves of the tested hydrogels during storage period: a) 7 days, b) 6 months and c) 24 months $(n=3$, all points in each rheogram have a coefficient of variation lower than $3 \%$ )

Slika 2. Krive tečenja ispitivanih hidrogelova tokom perioda čuvanja: a) 7 dana, b) 6 meseci i c) 24 meseca $(n=3$, koeficijenti varijacije svih predstavljenih tačaka manji su od 3\%) 
This type of flow is typical for aqueous dispersions of natural and synthetic polymers in which the presence of long, high molecular weight molecules in solution results in their entanglement with the association of immobilized solvent (33). Such flow behavior is of pharmaceutical and cosmetic interest in, for example, the case of semisolid formulations for application on the skin $(34,35)$. As can be seen from Figure 2, the thixotropy was slightly pronounced only for hydrogel $\mathrm{C}$, while it was negligible for the hydrogels with active substances during the storage period. Dinkgreve et al. (2018) (36) studied the effect of sample preparation protocol on the rheological behavior of $0.6 \%$ Carbopol ${ }^{\circledR}$ Ultrez U10 dispersion with $\mathrm{pH}$ adjusted to 7 . They observed the absence of thixotropy for a dispersion obtained through gentle stirring, while noticeable thixotropy for a dispersion prepared using intense, vigorous stirring over a prolonged period was recorded. The explanation for the obtained results was attributed to the athermal nature of swollen carbomer particles obtained in the gentle stirring protocol, resulting in a dispersion that does not show time evolution and hence does not show thixotropic behavior. Since the hydrogels investigated in our study were based on hydrogel C, which was prepared by stirring at a moderate speed $(300 \mathrm{rpm})$, their thixotropy was generally low or negligible.

The values of maximal apparent viscosity $\left(\eta_{\max }\right)$ and minimal apparent viscosity $\left(\eta_{\min }\right)$ of the tested hydrogels during the 24-month storage period are presented in Table III.

Table III Apparent viscosities $\eta_{\max }$ and $\eta_{\min }$ (at $4.11 / \mathrm{s}$ and $200.01 / \mathrm{s}$, respectively) of the tested hydrogels during storage period

Tabela III Vrednosti prividnih viskoziteta $\eta_{\max }$ i $\eta_{\min }$ (pri 4,1 1/s, odnosno 200,0 1/s) ispitivanih hidrogelova tokom perioda čuvanja

\begin{tabular}{|l|c|c|c|c|c|c|c|c|c|c|}
\hline \multirow{2}{*}{$\begin{array}{l}\text { Sample } \\
\text { label }\end{array}$} & \multicolumn{4}{|c|}{ Maximal apparent viscosity $\left(\eta_{\max }\right)(\mathrm{Pa} \cdot \mathrm{s})$ at } & \multicolumn{5}{c|}{ Minimal apparent viscosity $\left(\eta_{\min }\right)(\mathrm{Pa} \cdot \mathrm{s})$ at } \\
\cline { 2 - 13 } & $\mathrm{I}^{\mathrm{a}}$ & $\mathrm{II}^{\mathrm{b}}$ & $\mathrm{III}^{\mathrm{c}}$ & $\mathrm{IV}^{\mathrm{d}}$ & $\mathrm{V}^{\mathrm{e}}$ & $\mathrm{I}$ & $\mathrm{II}$ & $\mathrm{III}$ & $\mathrm{IV}$ & $\mathrm{V}$ \\
\hline $\mathrm{C}$ & 67.3 & 56.0 & 57.1 & 63.5 & 67.7 & 3.65 & 2.89 & 3.35 & 3.46 & 3.47 \\
\hline E & 19.5 & 17.0 & 19.2 & 18.7 & 17.8 & 1.32 & 1.08 & 1.34 & 1.21 & 1.28 \\
\hline EP & 10.4 & 8.73 & 9.16 & 7.45 & 6.51 & 0.72 & 0.59 & 0.71 & 0.59 & 0.56 \\
\hline G & 39.3 & 40.1 & 42.7 & 39.0 & 37.2 & 2.44 & 2.23 & 2.69 & 2.33 & 2.42 \\
\hline GP & 15.1 & 9.4 & 13.0 & 12.0 & 19.4 & 1.15 & 0.65 & 1.07 & 0.92 & 0.88 \\
\hline
\end{tabular}

a) 7 days; b) 1 month; ${ }^{\text {c) }} 3$ months; d) 6 months; e) 24 months 
The highest values of the minimal and maximal apparent viscosities of the hydrogels at the beginning of the study ( 7 days after preparation) were recorded for hydrogel base $\mathrm{C}$ (Table III). The viscosities of the hydrogels with pure active substances (E and $G$ ) were lower compared to hydrogel base $C$, while significantly lower values were detected in the hydrogels with the active substances in the phytosome form (EP and GP).

Plastic bodies have a yield value, i.e. a minimal shear stress must act on the system to initiate a flow process $(34,35)$. The yield stress/yield point of the tested hydrogels during the 24-month storage period are presented in Table IV.

Table IV Yield stress $\left(\tau_{0}\right)$ values of the tested hydrogels during storage period

Tabela IV Vrednosti napona popuštanja $\left(\tau_{0}\right)$ ispitivanih hidrogelova tokom perioda čuvanja

\begin{tabular}{|l|c|c|c|c|c|}
\hline \multirow{2}{*}{ Sample label } & \multicolumn{5}{|c|}{ Yield stress $\left(\tau_{0}\right)(\mathrm{Pa})$} \\
\cline { 2 - 6 } & $\mathrm{I}^{\mathrm{a}}$ & $\mathrm{II}^{\mathrm{b}}$ & $\mathrm{III}^{\mathrm{c}}$ & $\mathrm{IV}^{\mathrm{d}}$ & $\mathrm{V}^{\mathrm{e}}$ \\
\hline C & 126.0 & 151.0 & 123.0 & 157.0 & 138.0 \\
\hline EP & 49.9 & 45.9 & 48.5 & 53.6 & 45.3 \\
\hline G & 25.3 & 23.5 & 23.9 & 20.3 & 17.1 \\
\hline GP & 102.0 & 101.0 & 110.0 & 107.0 & 84.2 \\
\hline
\end{tabular}

a) 7 days; b) 1 month; ${ }^{\text {c) }} 3$ months; d) 6 months; e) 24 months

It is known that the magnitude of yield stress is a measure of the strength of the closed-pack structure that must be exceeded for the material to flow appreciably (37). The yield value is not a material constant, because it depends on the sample's pretreatment and the measuring method used, as well as on the evaluation method used (28). There are several methods used for the determination of this parameter: a) via mathematical curvefitting models for flow curves (on a linear scale); b) determination of the yield point using a low curve diagram on a logarithmic scale; c) determination of the yield point from limit of the linear-elastic region or d) from oscillatory experiments, by carrying out a strain sweep at a fixed frequency of oscillation $(28,36,37)$. Each of the abovementioned methods has its advantages and limitations. The yield stress values depend on the method used for its determination, so it is possible to obtain results that differ from each other by 2-3 times, depending on the applied method $(36,37)$. In our study, the method applied was the reading of the yield point using a flow curve diagram on a logarithmic scale at the lowest shear rate, and it enabled a simple, fast and reproductive determination, with a coefficient of variation lower than $3 \%$. As can be seen from Table IV, the highest yield stress/yield point value was determined for hydrogel base C. As expected, the values of this parameter were lower for hydrogels $\mathrm{E}$ and $\mathrm{G}$ and the lowest for phytosome-loaded hydrogels EP and GP. The obtained results clearly proved that the incorporation of active 
substances, especially in the form of phytosomes, changed the consistency and decreased the apparent viscosity and yield stress/yield point of the carbomer hydrogel. To elucidate the influence of different forms of active substances on the structure of the carbomer hydrogel, an oscillatory rheological analysis was performed. Under the applied stress, ideal liquids flow and perfectly elastic solids deform. In general, gels are semisolids that have both solid and liquid character under stress, thus they are viscoelastic systems (38). To obtain information on the internal structure of viscoelastic systems, static (i.e. creep and relaxation experiments) or dynamic experiments can be performed. Within dynamic experiments, the sample is exposed to a forced sinusoidal oscillation and the transmitted stress is measured. Both types of testing are used for the evaluation of structure and physical aging of aqueous dispersions of carbomer gels (17, 39-41). The results of the oscillatory rheological characterization of the investigated hydrogels are presented in Table V and Figure 3.

Table $\mathbf{V}$ The elastic $\left(\mathrm{G}^{\prime}\right)$ modulus, viscous (G") modulus and $\tan \delta$ of the tested hydrogels during storage period

Tabela V Vrednosti elastičnog modula ( $\left.G^{\prime}\right)$, viskoznog modula (G") i faznog ugla ( $\tan \delta$ ) ispitivanih hidrogelova u toku perioda čuvanja

\begin{tabular}{|c|c|c|c|c|c|c|c|c|c|c|c|c|c|c|c|}
\hline \multirow{2}{*}{$\begin{array}{l}\text { Sample } \\
\text { label }\end{array}$} & \multicolumn{5}{|c|}{$\mathrm{G}^{\prime}(\mathrm{Pa})$} & \multicolumn{5}{|c|}{$\mathrm{G}^{\prime \prime}(\mathrm{Pa})$} & \multicolumn{5}{|c|}{$\tan \delta$} \\
\hline & $\mathrm{I}^{\mathrm{a}}$ & $\mathrm{II}^{\mathrm{b}}$ & $\mathrm{III}^{\mathrm{c}}$ & $\mathrm{IV}^{\mathrm{d}}$ & $\mathrm{V}^{\mathrm{e}}$ & I & II & III & IV & V & I & II & III & IV & V \\
\hline $\mathrm{C}$ & 713.0 & 517.0 & 769.5 & 594.5 & 700.0 & 349.5 & 227.0 & 315.0 & 290.5 & 237.0 & 0.493 & 0.438 & 0.410 & 0.492 & 0.338 \\
\hline $\mathrm{E}$ & 281.5 & 376.5 & 383.5 & 200.0 & 295.6 & 280.0 & 255.5 & 275.0 & 152.5 & 201.0 & 0.895 & 0.656 & 0.738 & 0.759 & 0.683 \\
\hline EP & 416.0 & 45.2 & 249.5 & 290.7 & 72.05 & 435.5 & 61.1 & 319.0 & 310.9 & 60.85 & 1.290 & 1.339 & 1.280 & 1.044 & 0.843 \\
\hline $\mathrm{G}$ & 493.5 & 444.0 & 660.0 & 608.0 & 553.0 & 304.5 & 225.5 & 302.5 & 300.0 & 260.0 & 0.630 & 0.506 & 0.458 & 0.495 & 0.473 \\
\hline GP & 303.5 & 165.5 & 248.5 & 210.0 & 168.0 & 287.0 & 210.5 & 277.0 & 218.7 & 173.2 & 0.831 & 1.285 & 1.078 & 0.998 & 0.976 \\
\hline
\end{tabular}

a) 7 days; b) 1 month; ${ }^{\text {c) }} 3$ months; d) 6 months; e) 24 months 


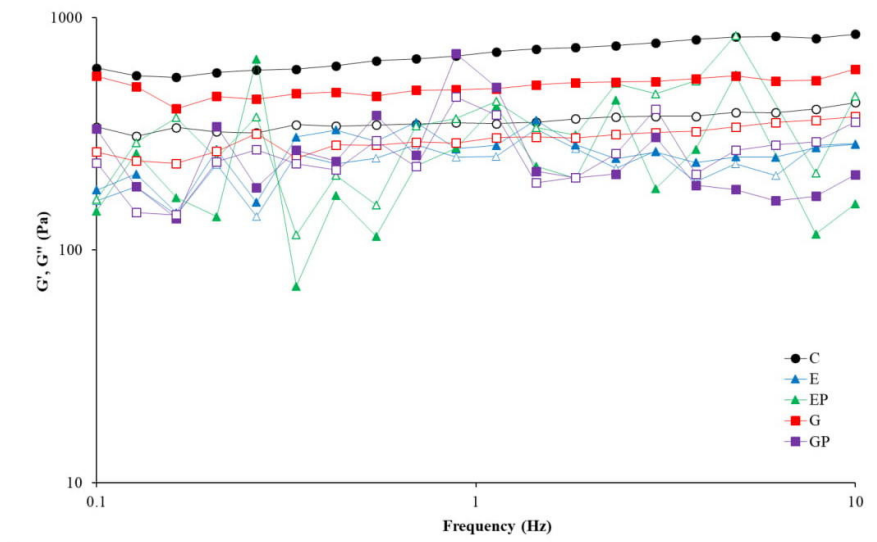

a)

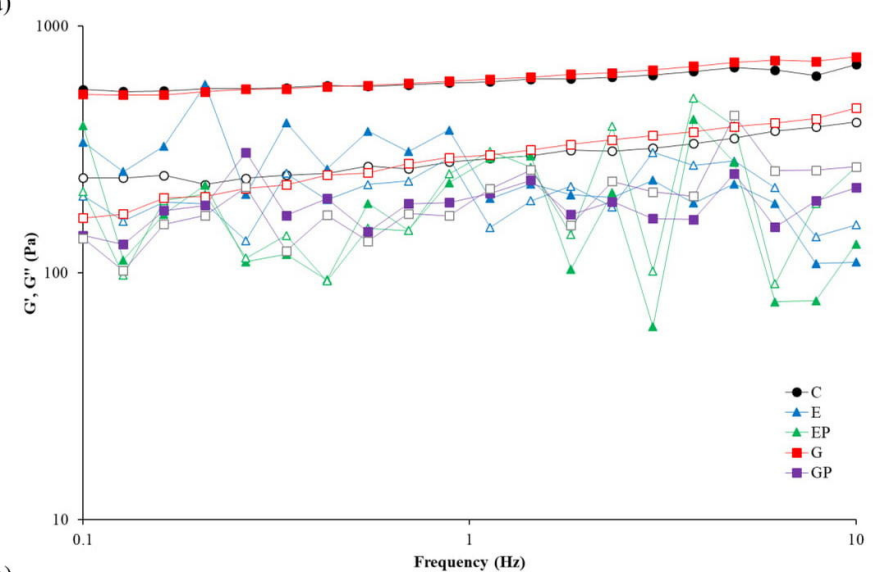

b)

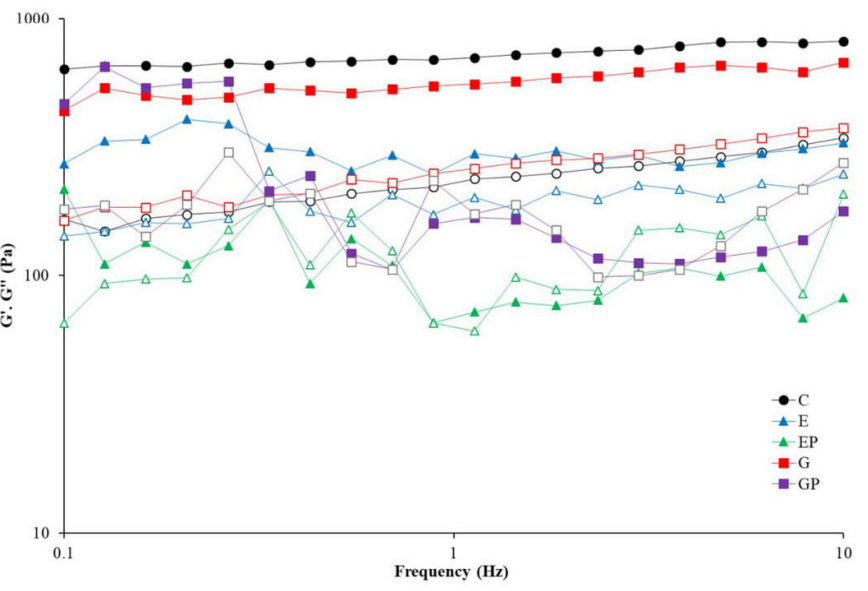

Figure 3. The dependence of the elastic (G', closed symbols) and viscous (G', open symbols) moduli on frequency for the hydrogels during storage period. Legend represents symbols for $G^{\prime}(n=3$, coefficients of variation were lower than $10 \%$ for all points)

Slika 3. Promena elastičnog (G', puni simboli) i viskoznog (G”, prazni simboli) modula sa frekvencijom ispitivanih hidrogelova u toku perioda čuvanja. Legenda predstavlja simbole za G' $(n=3$, koeficijent varijacije svih predstavljenih tačaka bio je manji od $10 \%$ ) 
The highest values of elastic (G') and viscous (G') moduli, i.e., the lowest value for tan $\delta$ for freshly prepared samples, were obtained for hydrogel base $\mathrm{C}$. These results were in correlation with the highest yield stress values (Table IV), indicating that this hydrogel had a stronger network structure than the others. The addition of escin and $18-\beta$ glycyrrhetinic acid as pure active substance (samples $\mathrm{E}$ and $\mathrm{G}$ ), did cause a decrease in values of $G^{\prime}$ and an increase of $\tan \delta$, indicating a weakening of the gel structure. As can be seen in Figure 3, during frequency sweep testing, $G^{\prime}>G^{\prime}$ ' in case of hydrogels $C$, $\mathrm{E}$ and $\mathrm{G}$, indicated the fulfilment of the precondition for physical dispersion stability and the long-term storage stability of these samples (28). However, in the hydrogel prepared with the active substances in the form of phytosomes (samples EP and GP), the values of G' were lower compared to hydrogels $E$ and $G$. The observed G' $<$ G' during frequency sweep testing of EP and GP (Figure 3) pointed out more pronounced viscous over elastic properties and coincided with the much softer consistency of these hydrogels. It is well known that the adjustment of $\mathrm{pH}$ value near neutral enables the ionization of the carboxylic groups and expansion of carbomer chains, accompanied by a huge increase in viscosity and elasticity and formation of the hydrogel (18). Additionally, few studies (12, $18,20)$ have shown that the addition of non-ionic surfactants, in concentrations above a critical association concentration, into carbomer gels, led to the surfactant/carbomer interactions, which were reflected in decreased viscosity and elasticity. In such systems, the surfactant molecules surround the carbomer microgels and thereby break the interpolymer connections and reduce their contribution to the elasticity of the hydrogel. The influence of the investigated phytosomes on the rheological properties of carbomer hydrogels can be interpreted in a similar way. Phytosomes have amphiphilic properties, so it can be assumed that they were immersed in the aqueous dispersion of carbomer microgels between which interpolymer interactions are interrupted, and thus the apparent viscosity and the elastic modulus of hydrogels EP and EG were significantly reduced. The influence of pure substances was less pronounced, due to generally lower amphiphilicity in comparison to the phytosomes. It was also observed that the reduction of apparent viscosity and elastic modulus was more pronounced in E vs. G and EP vs. GP (Table III, Table V). This was related to the weak amphiphilic properties of escin itself (42). Escin used in this study is a mixture of 4 isomeric saponosides whose molecules consist of a poorly soluble aglycone protoescigenin and a water-soluble glycone, so it shows surface activity in water solutions (42). On the other hand, 18- $\beta$ glycyrrhetinic acid (syn. enoxolone) is a pentacyclic triterpenoid derivative of beta-amyrin practically insoluble in water $(25,43)$. Therefore, considerably higher interactions between the active substance and carbomer, as well as a more extensive effect on rheological properties, could be expected in hydrogels E and EP in comparison to G and GP, respectively.

\section{Physical stability of hydrogels}

The appearance of the samples was checked periodically during the storage. The appearance and consistency of hydrogel $\mathrm{C}$ did not change for 24 months (Figure 1). The appearance and consistency of the hydrogels with the investigated active substances both 
pure (E and G) and in the phytosome form (EP and GP), also did not change significantly after the 24-month storage under ambient conditions (Figure 1). The characteristic isopropyl alcohol odor was detected for all the investigated hydrogels during the 24-month study. During the storage period, the major changes in terms of viscosities reduction were observed after 30 days, while after this period the changes of the observed parameters were less pronounced. The observed changes could be attributed to the structuration of the systems, which usually occurs after a couple of days or, in some cases, after a couple of months, as it was already observed in liposomal gels for topical application stabilized with carbomer polymers (44). After a period of 24 months, the lowest fluctuations in apparent viscosities, compared to the initial values, were detected in hydrogels $\mathrm{C}$ and $\mathrm{G}$ (less than 5\%), followed by hydrogel $\mathrm{E}$ (reduction of about to $10 \%$ ). The observed fluctuations were more extensive for hydrogel GP (up to 30\%) and hydrogel EP (more than 30\%). Moreover, the largest decrease during the storage period was detected for hydrogel EP, which had the lowest values of $\eta_{\max }, \eta_{\min }$ and $\tau_{0}$ (Table III and Table IV). Changes in yield stress/yield point of the investigated hydrogels (Table IV) during the 24-month storage period were consistent with the observed changes in the apparent viscosities.

The values of G', G', and tan $\delta$ for hydrogel base $\mathrm{C}$ remained the highest, and they did not change significantly during the overall storage period. The choice of Carbopol ${ }^{\circledR}$ Ultrez 10 was consistent with the observation that it forms hydrogels which are not susceptible to water loss as a result of temperature variation from $5 \pm 3{ }^{\circ} \mathrm{C}$ up to $+40{ }^{\circ} \mathrm{C}$ (27). Also, Carbopol ${ }^{\circledR}$ Ultrez 10 is compatible with high concentrations of alcohols, botanical extracts and emollients (32), disperses quickly, and the obtained gels provide superior clarity, smoothness and non-tacky feel compared to traditional carbomers (45). In the case of hydrogels with pure substances ( $E$ and $G$ ), more pronounced elastic properties compared to the viscous ones were preserved during the entire duration of the study, while the hydrogels with phytosomes (EP and GP) had a permanently less pronounced elastic character. The average tan $\delta$ values of $1.159 \pm 0.210$ (EP) and $1.057 \pm 0.137$ (GP) revealed that the tested hydrogels, although of semisolid consistency, had slightly more pronounced viscous than elastic properties; however, they also indicate that phytosome-loaded hydrogels could be susceptible to segregation (28), in this case settling (sedimentation) of dispersed phytosomes. Although the values of G', G' and tan $\delta$ for hydrogels EP and GP did not change significantly in the period between 6 months and 2 years of storage, their alterations may indicate the need for monitoring at shorter time intervals in order to comprehensively assess the long-term stability of these samples.

\section{Conclusions}

The hydrogels loaded with phytosomes of escin and 18- $\beta$ glycyrrhetinic acid were homogeneous, opalescent or turbid, soft semisolids. They spread easily on the skin and left a thin film and cooling effect. Phytosome incorporation did not significantly affect the $\mathrm{pH}$ values of the hydrogels throughout the study and they were physiologically 
acceptable. Despite slight changes in $\mathrm{pH}$, which could not affect the carbomer gelling ability, the incorporation of phytosomes in the hydrogel led to a noticeable softening of the consistency. The continuous rheological characterization enabled detection of a significant reduction in the apparent viscosities and yield stresses in the phytosomeloaded hydrogels, while changes in these rheological parameters were smaller when pure active substances were used. Moreover, the results of oscillatory rheological analysis clearly indicated that, in the presence of phytosomes, there were changes in the strength of the carbomer gel network (ascribed to interactions of amphiphilic complexes with the polymer and breaking bonds between microgel domains), due to which they had predominantly viscous behavior and less pronounced elastic properties. The observed reduction in elastic properties did not have a negative effect on the spreading of hydrogels on the skin; however, it should be further considered as a risk for sedimentation of phytosomes during the storage time. The absence of significant variations in the values of the examined rheological parameters proved the satisfactory physical stability of the phytosome-loaded hydrogels during 24 months of storage under ambient conditions. In addition, the overall rheological characterization of hydrogels enabled the assessment and comparison of structural changes caused by the incorporation of phytoconstituents of different amphiphilicity, both pure and in the form of phytosomes. A greater influence was detected in the presence of escine phytosome versus $18-\beta$ glycyrrhetinic acid phytosome, as well as for amphiphilic escin in comparison to poorly soluble $18-\beta$ glycyrrhetinic acid.

\section{Acknowledgement}

The authors would like to thank Indena S.p.A. (Italy) for providing the gift samples of escin, Escin $\beta$-Sitosterol Phytosome ${ }^{\circledR}, 18-\beta$ glycyrrhetinic acid, 18- $\beta$ Glycyrrhetinic Acid Phytosome ${ }^{\circledR}$.

\section{Funding}

This research was funded by the Ministry of Education, Science and Technological Development of the Republic of Serbia through Grant Agreement with the University of Belgrade-Faculty of Pharmacy No: 451-03-9/2021-14/200161.

\section{Declarations of interest: none.}




\section{References}

1. Saraf AS. Applications of novel drug delivery system for herbal formulations. Fitoterapia 2010;81(7):680-9.

2. Djekic L, Krajisnik D, Micic Z. Polyphenolics-phospholipid complexes as natural cosmetic ingredients: Properties and application. Tenside Surfact. Det. 2015;52(3):186-92.

3. Karimi N, Ghanbarzadeh B, Hamishehkar H, Keivani F, Pezeshki A, Gholian MM. Phytosome and Liposome: The Beneficial Encapsulation Systems in Drug Delivery and Food Application. Appl. Food Biotechnol. 2015;2(3):17-27.

4. Semalty A, Semalty M, Rawat MSM, Franceschi F. Supramolecular phospholipids-polyphenolics interactions: The PHYTOSOME ${ }^{\circledR}$ strategy to improve the bioavailability of phytochemicals. Fitoterapia 2010;81(5):306-14.

5. Alam MA, Al-Jenoobi FI, Al-mohizea AM. Commercially bioavailable proprietary technologies and their marketed products. Drug Discov. Today 2013;18(19/20):936-49.

6. Indena ${ }^{\circledR}$ Product List. DPR0002 - 03/2011*02/2020 [Internet]. Indena S.p.A. 2020 [cited 2021 Jan 30]. Available from: https://www.indena.com/indena_files/2020/02/Indena-product_list_2020.pdf.

7. Ahmed EM. Hydrogel: Preparation, characterization, and applications: A review. J. Adv. Res. 2015;6(2):105-21.

8. Gyles DA, Castro LD, Júnior JOC, Ribeiro-Costa RM. The designs and prominent biomedical advances of natural and synthetic hydrogel formulations. Eur. Polym. J. 2017;88:373-92.

9. Peppas NA, Bures P, Leobandung W, Ichikawa H. Hydrogels in pharmaceutical formulations. Eur. J. Pharm. Biopharm. 2000;50(1):27-46.

10. Tasić Kostov M, Arsić I, Pavlović D, Stojanović S, Najman S, Ilić D, Tadić V. Alchemilla vulgaris L. extract in hydrogel vehicle: in vivo/in vitro evaluation of skin safety profile and wound healing potential in threatment of minor cutaneous wounds. [Hidrogel sa ektraktom Alchemilla vulgaris L.: in vivo/in vitro procena bezbednosti i uticaja na zarastanje manjih rana na koži]. Arh. farm. 2018;68(3):645-6.

11. Jončić-Savić K, Pešić J, Rajić M, Lukić M, Jakšić I, Milić J, Savić S, Vuleta G. The influence of different formulation factors on physicochemical and biopharmaceutical characteristics of ketoprofen 2,5\% gel. [Uticaj faktora formulacije na fizičkohemijske i biofarmaceutske karakteristike ketoprofen 2,5\% gela]. Arh. farm. 2010;60:1237-55.

12. Paulsson M, Edsman K. Controlled drug release from gels using surfactant aggregates: I. Effect of Lipophilic Interactions for a Series of Uncharged Substances. J. Pharm. Sci. 2001;90(9):1216-25.

13. Xu H, Wen Y, Chen S, Zhu L, Feng R, Song Z. Paclitaxel skin delivery by micelles-embedded Carbopol 940 hydrogel for local therapy of melanoma. Int. J. Pharm. 2020;587:119626. doi.org/10.1016/j.ijpharm.2020.119626.

14. Djekic L, Martinović M, Dobričić V, Čalija B, Medarević Đ, Primorac M. Comparison of the effect of bioadhesive polymers on stability and drug release kinetics of biocompatible hydrogels for topical application of ibuprofen. J. Pharm. Sci. 2019;108(3):1326-33.

15. Graziano R, Preziosi V, Uva D, Tomaiuolo G, Mohebbi B, Claussen J, Guido S. The microstructure of Carbopol in water under static and flow conditions and its effect on the yield stress. J. Colloid. Interface. Sci. 2021;582(Pt B):1067-74. 
16. Dinkgreve M, Fazilati M, Denn M, Bonn D. Carbopol: from a simple to a thixotropic yield stress fluid. J. Rheol. 2018;62(3):773-80.

17. Agarwal M, Joshi YM. Signatures of physical aging and thixotropy in aqueous dispersion of Carbopol. Phys. Fluids 2019;31(6):063107. doi.org/10.1063/1.5097779.

18. Barreiro-Iglesias R, Alvarez-Lorenzo C, Concheiro A. Incorporation of small quantities of surfactants as a way to improve the rheological and diffusional behavior of carbopol gels. J. Control. Release 2001;77(1-2):59-75.

19. Barreiro-Iglesias R, Alvarez-Lorenzo C, Concheiro A. Poly(acrylic acid) microgels (carbopol® 934)/ surfactant interactions in aqueous media Part I: Nonionic surfactants. Int. J. Pharm. 2003;258(1-2):165-77.

20. Barreiro-Iglesias R, Alvarez-Lorenzo C, Concheiro A. Controlled release of estradiol solubilized in carbopol/surfactant aggregates. J. Control. Release 2003;93(3):319-30.

21. Technical Datasheet 5277. Escin b- Sitosterol Phytosome Indena [Internet]. Farmalabor Srl, Canosa di Puglia (Italy) [cited 2021 Jan 30]. Available from: https://www.farmalabor.it/schede/2017/6881301.PDF.

22. Bombardelli E, Patri GF, Pozzi R. Complexes of saponins with phospholipids and pharmaceutical and cosmetic compositions containing them [Internet]. Munich, Germany: European Patent Office. European Patent: EP 0283713 B1, 1993 [cited 2021 Jan 30]. Available from: https://patents.google.com/patent/EP0283713A2/en.

23. Curri SB, Bombardelli E, Della Loggia R, Del Negro P, Tubaro A. Topical antiinflammatory activity of complexes of aescin and sterols with phospholipids, Part II: Anti-oedema properties in the treatment of panniculopathies of the thigts and breast. Fitoterapia 1989;60:45-53.

24. Djekic L, Čalija B, Micov A, Tomić M, Stepanović-Petrović R. Topical hydrogels with escin $\beta$ sitosterol phytosome and escin: Formulation development and in vivo assessment of antihyperalgesic activity. Drug Dev. Res. 2019;80(7):921-32.

25. Technical Datasheet 5256. 18 Beta Glycyrrhetic Acid Phytosome Indena [Internet]. Farmalabor Srl, Canosa di Puglia (Italy). [cited 2021 Jan 30]. Available from: https://materie-prime.farmalabor.it/schede/6394529.PDF.

26. Kowalska A, Kalinowska-Lis U. 18ß-Glycyrrhetinic acid: its core biological properties and dermatological applications. Int. J. Cosmet. Sci. 2019;41(4):325-31.

27. Djekic L, Krajišnik D, Mićić Z, Čalija B. Formulation and physicochemical characterization of hydrogels with 18ß-glycyrrhetinic acid/phospholipid complex phytosomes. J. Drug Deliv. Sci. Technol. 2016;35:81-90.

28. Mezger TG. Applied Rheology: with Joe Flow on Rheology Road. Graz: Anton Paar; 2015; p. 47-51.

29. Escin $\beta$-Sitosterol Phytosome ${ }^{\circledR}$ Datasheet. Escin and Escin $\beta$-Sitosterol Phytosome ${ }^{\circledR}$ Indena S.p.A., 2017 [Internet]. Indena S.p.A (Italy) [cited 2021 Jan 30]. Available from: https://www.ulprospector.com/en/eu/PersonalCare/Detail/2736/81738/Escin--Sitosterol-Phtosome.

30. 18- $\beta$ Glycyrrhetinic Acid Phytosome ${ }^{\circledR}$ Datasheet. 18- $\beta$ Glycyrrhetinic Acid and 18- $\beta$ Glycyrrhetinic Acid Phytosome® Indena S.p.A., 2016 [Internet]. Indena S.p.A (Italy) [cited 2021 Jan 30]. Available from: https://www.ulprospector.com/en/eu/PersonalCare/Detail/2736/226137/18--GlycyrrhetinicAcid-Phytosome 
31. Lambers H,Piessens S, Bloem A, Pronk H, Finkel P. Natural skin surface $\mathrm{pH}$ is on average below 5, which is beneficial for its resident flora. Int. J. Cosmet. Sci. 2006;28(5):359-70.

32. TDS-255 Formulating Hydroalcoholic Gels with Carbopol ${ }^{\circledR}$ Polymers [Internet]. The Lubrizol, Technical Data Sheet, Edition: September 3, 2009. [cited 2021 Jan 30]. Available from: https://www.lubrizol.com/Personal-Care/Literature.

33. Marriott C. Rheology. In Aulton ME, Taylor KM, editor(s). Aulton's Pharmaceutics E-Book: The Design and Manufacture of Medicines. Elsevier Health Sciences: 2018; p. 93-114.

34. Sakamoto K, Lochhead R, Maibach H, Yamashita Y, editor(s). Cosmetic science and technology: theoretical principles and applications. Amsterdam: Elsevier: 2017; p. 643.

35. Fahr A. Voigt's Pharmaceutical Technology. Hoboken, Chichester: John Wiley \& Sons; 2018; p. 122-23.

36. Dinkgreve M, Paredes J, Denn MM, Bonn D. On different ways of measuring "the" yield stress. J. non-Newton. Fluid. 2016;238:233-41.

37. Islam MT, Rodriguez-Hornedo N, Ciotti S, Ackermann C. Rheological characterization of topical carbomer gels neutralized to different pH. Pharm. Res. 2004;21(7):1192-9.

38. Ofner CM, Klech-Gelotte CM. Gels and Jellies. In Swarbrick J, editor. Encyclopedia of pharmaceutical technology. 3rd ed. New York: Marcel Dekker; 2007; p.1880-1.

39. Tamburic S, Craig DQ. The effects of ageing on the rheological, dielectric and mucoadhesive properties of poly (acrylic acid) gel systems. Pharm. Res. 1996;13:279-83.

40. Joshi YM, Petekidis G. Yield stress fluids and ageing. Rheol. Acta, 2018;57:521-49.

41. Lidon P, Villa L, Manneville S. Power-law creep and residual stresses in a carbopol gel. Rheol. Acta, 2017;56:307-23.

42. Geisler R, Dargel C, Hellweg T. The Biosurfactant $\beta$-Aescin: A Review on the Physico-Chemical Properties and Its Interaction with Lipid Model Membranes and Langmuir Monolayers. Molecules 2020;25:117. doi:10.3390/molecules25010117.

43. Darvishi B, Manoochehri S, Kamalinia G, Samadi N, Amini M, Mostafavi SH, Maghazei S, Atyabi F, Dinarvand R. Preparation and antibacterial activity evaluation of 18- $\beta$-glycyrrhetinic acid loaded PLGA nanoparticles. Iran. J. Pharm. Res. 2015;14(2):373-83.

44. Dragicevic-Curic N, Winter S, Krajisnik D, Stupar M, Milic J, Graefe S, Fahr A. Stability evaluation of temoporfin-loaded liposomal gels for topical application. J. Liposome Res. 2010;20(1):38-48.

45. TDS-225 Carbopol® Ultrez 10 Polymer for Personal Care Applications [Internet]. Lubrizol, Technical Data Sheet, Edition: January, 2002 [cited 2021 Jan 30]. Available from: https://www.lubrizol.com/Personal-Care/Literature. 


\title{
Ispitivanje reološkog ponašanja i njegov značaj za procenu aplikativnih svojstava i fizičke stabilnosti hidrogelova sa fitosomima
}

\author{
Ljiljana Đekic $^{1}$, Danina Krajišnik ${ }^{1^{*}}$ \\ ${ }^{1}$ Univerzitet u Beogradu - Farmaceutski fakultet, Katedra za farmaceutsku tehnologiju i \\ kozmetologiju, Vojvode Stepe 450, 11221 Belgrad, Srbija
}

*Autor za korespondenciju: Danina Krajišnik, E-mail: danina.krajisnik@pharmacy.bg.ac.rs

\section{Kratak sadržaj}

Fitosomi su amfifilni molekulski kompleksi supstanci biljnog porekla i fosfolipida koji se razmatraju kao aktivni sastojci dermofarmaceutskih i kozmetičkih formulacija potencijalno unapređene efikasnosti. Cilj studije bio je formulacija karbomernih hidrogelova sa komercijalno

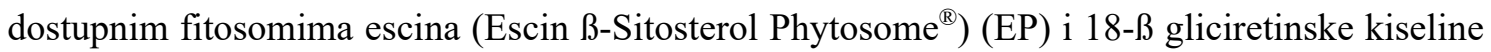
(18-ß Glycyrrhetinic Acid Phytosome ${ }^{\circledR}$ ) (GP) i njihova karakterizacija u cilju procene aplikativnih svojstava i fizičke stabilnosti u realnom vremenu. Inkorporiranje fitosoma nije značajno uticalo na $\mathrm{pH}$ hidrogelova, koji je bio prihvatljiv za primenu na koži. Međutim, ovi hidrogelovi imali su značajno različite organoleptičke osobine (neprozirni i mekše konzistencije) u poređenju sa hidrogelom bez aktivne supstance (C) i odgovarajućim hidrogelovima sa čistim aktivnim supstancama (E i G) koji su upotrebljeni za poređenje. Vrednosti maksimalnog i minimalnog prividnog viskoziteta i napon popuštanja bili su značajno niži kod hidrogelova sa fitosomima. Rezultati oscilatorne reološke analize ukazali su da kod hidrogelova EP i GP preovlađuje viskozni karakter (elastični modul $\left(G^{\prime}\right)<$ viskozni modul $\left(G^{\prime \prime}\right)$ ), dok su kod hidrogelova $C$, E i G bila izraženija elastična svojstva $\left(G^{\prime}>G^{\prime \prime}\right)$. Fitosom escina je imao veći uticaj na jačinu karbomerne gelske mreže. Hidrogelovi sa fitosomima bili su fizički stabilni tokom 24 meseca čuvanja pod ambijentalnim uslovima, mada su rezultati reološke analize ukazali na potencijalni rizik od sedimentacije.

Ključne reči: fitosomi, hidrogel, reološka karakterizacija, aplikativna svojstva, fizička stabilnost 